\title{
FORMATION OF VIABLE CELL FRAGMENTS BY TREATMENT WITH COLCHICINE
}

\author{
T. CREMER, C. ZORN, C. CREMER and J. ZIMMER \\ Institute of Human Genetics, University of Freiburg, D-78 Freiburg i.Br., Germany
}

\begin{abstract}
SUMMARY
Time-lapse cinematography of human fibroblasts revealed that mitotic cells separated into numerous cell fragments containing varying amounts of chromatin and cytoplasm when treated with colchicine. As cell fragments were very loosely attached to the surface of the culture vessel during their formation, they could be easily detached like mitotic cells by gently shaking the vessel and thus separated from normal interphase cells. Fragments obtained by this procedure were able to exclude trypan blue indicating, therefore, an intact cell membrane. When placed into Petri dishes many of them attached to and even spread out on the surface. Five hours later the majority of the attached fragments incorporated $\left[{ }^{3} \mathrm{H}\right]$ leucine. Time-lapse films showed that fragments were able to extend and retract pseudopodia at least for several hours after their formation. Although the fragments degenerated within a few days, in the present experiments the possibility was not excluded that fragments which had lost only a very small amount of chromatin and cytoplasm survived for longer periods of time. The observations clearly indicate viability of many newly formed fragments.
\end{abstract}

Colchicine can be used to experimentally fragment the nuclei of cells into a number of separate karyomeres each presumably containing some or only one of the chromosomes of the complement [1]. The present paper shows that human fibroblasts treated with low doses of colchicine can not only form multinucleate cells but also split up into numerous cell fragments. The morphology of such fragments and results of viability tests thereof are described below.

\section{MATERIAL AND METHODS}

\section{Cells and cultivation procedures}

Two strains of human fibroblasts were used for the experiments. If not stated otherwise the results refer to experiments performed with strain 1 which was derived from skin biopsy of a 3-month-old male baby. The karyotype was a normal $46 \mathrm{XY}$. Strain 2 was derived from the Fascia lata of a 9-year-old boy. The karyotype of the latter was not investigated. Cells were grown in Eagle's MEM supplemented with nonessential amino acids and $12 \%$ fetal calf serum (FCS), in a humidified atmosphere with $5 \% \mathrm{CO}_{2}$ at $37^{\circ} \mathrm{C}$. Cultures were subcultivated when they reached confluency using a 2:1 split ratio [2]. During the experiments the strains were in phase II of their lifespans [2].

\section{Production of cell fragments}

Confluent cultures were trypsinized and the cells were sown into Roux flasks using a 3:1 split ratio. Two days later colchicine (Biocult Laboratories) was added to give a final concentration of $0.02-0.04 \mu \mathrm{g} / \mathrm{ml}$ of medium. Untreated cultures of the same passages served as controls. Twenty-four hours later the medium was removed and the cell layer was washed by one rinse of MEM without FCS. Then $2 \mathrm{ml}$ of a trypsin solution $(0.01 \%$ trypsin in MEM without FCS) were added and the flasks were agitated slightly for 2-3 min. In later experiments only $2 \mathrm{ml}$ of MEM without FCS were used instead of the trypsin solution. By this procedure mitotic cells and many cell fragments were predominantly detached from the glass surface while most interphase cells remained attached. The mediumcontaining an enrichment of cell fragments and mitotic 

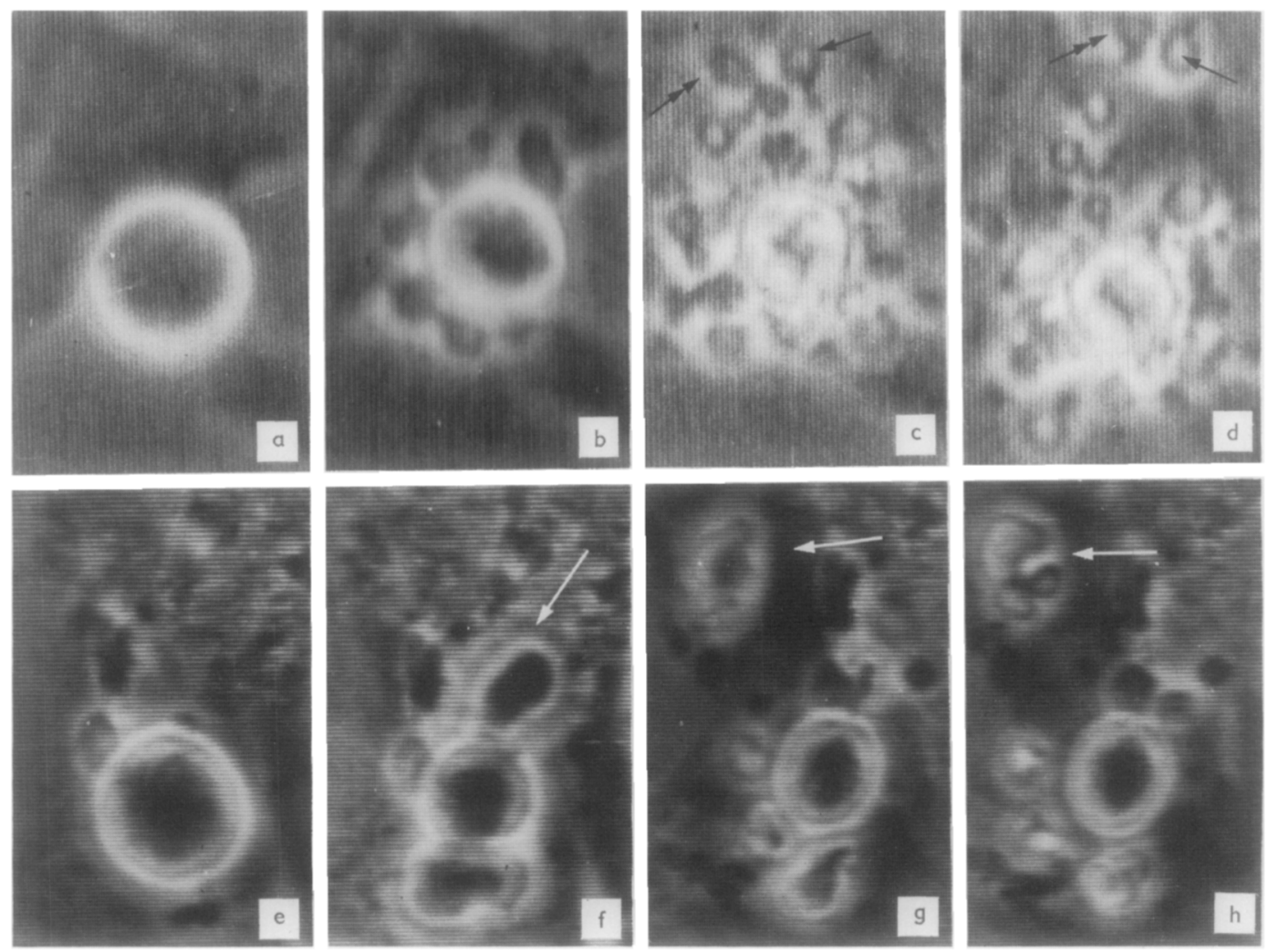

Fig. 1. $(a-d),(e-h)$ Process of fragmentation of two mitotic cells from a culture treated with colchicine. The photographs were taken from a television screen. Time-lapse cinematography started only after the two cells had entered mitosis. No alteration of the ballshaped form was detectable during 5 and $2.5 \mathrm{~h}$, respectively, of continuous observation. Time (min) (a) 0 ; (b) $0.5 ;(c) 16.5 ;(d) 17.5 ;(e) 0 ;(f) 1 ;(g) 13.8 ;(h) 17.8$ is given with reference to time 0 directly before the first protrusion was observed. $(a),(e)$ Ball-shaped cells

cells as established by cytological examination-was removed and diluted with MEM. Dispersion of the cell fragments was done by repeatedly pipetting the suspension. Finally FCS (12\%) was added. The final product established by this experimental procedure is referred to as fragment-suspension though it contains, of course, a certain amount of normal cells. Fragment-suspensions were pipetted into plastic Petri dishes (Nunc, $\varnothing 5 \mathrm{~cm}$ ) and incubated in a $5 \% \mathrm{CO}_{2}$ humiditied atmosphere at $37^{\circ} \mathrm{C}$ for various time intervals. The medium was afterwards removed, the dishes were washed by three rinses of Hanks' BSS and fixation was performed with methanol. Those cells and cell fragments which remained attached to the dish during this procedure constitute a sample.

Colchicine-treated cultures, samples and control dishes were stained with acridine orange for fluorescence microscopy. Cells and cell fragments were during mitosis before the process of fragmentation; (b) formation of several protrusions; Fig. $(c),(d)$ numerous fragments that have constricted off completely. The arrows point to some fragments that moved away from their sites of formation. The number of fragments formed by the mitotic cell $(e)-(h)$ was much smaller. Change of form and formation of further constrictions in the fragment marked by arrows in $(f)$ (h) may be noticed. $\times 650$.

photographed using a Zeiss fluorescence microscope (transmittance light, dark field, Apochromat $40 \times / 1.0$ oil, iris). Other samples and controls were stained with hematoxylin-eosin or Giemsa. All cells and cell fragments contained in randomly chosen fields were photographed or were drawn at $500 \times$ magnification using a microscope with a drawing tubus (Wild-Heerbrugg, $50 \times \mathrm{Ph} / \mathrm{oil}$ ). The areas of the nuclei and micronuclei, and the areas occupied on the dish surface by metry of either photographs or drawings.

\section{Trypan blue exclusion test}

Fragment-suspensions were centrifuged for 5-10 min at about $50 \mathrm{~g}$. The pellet was diluted in a trypan blue solution in PBS (final dye concentration $36 \mathrm{mg} \%$ ). Stained and non-stained cells and cell fragments were cells and cell fragments, were determined from plani- 

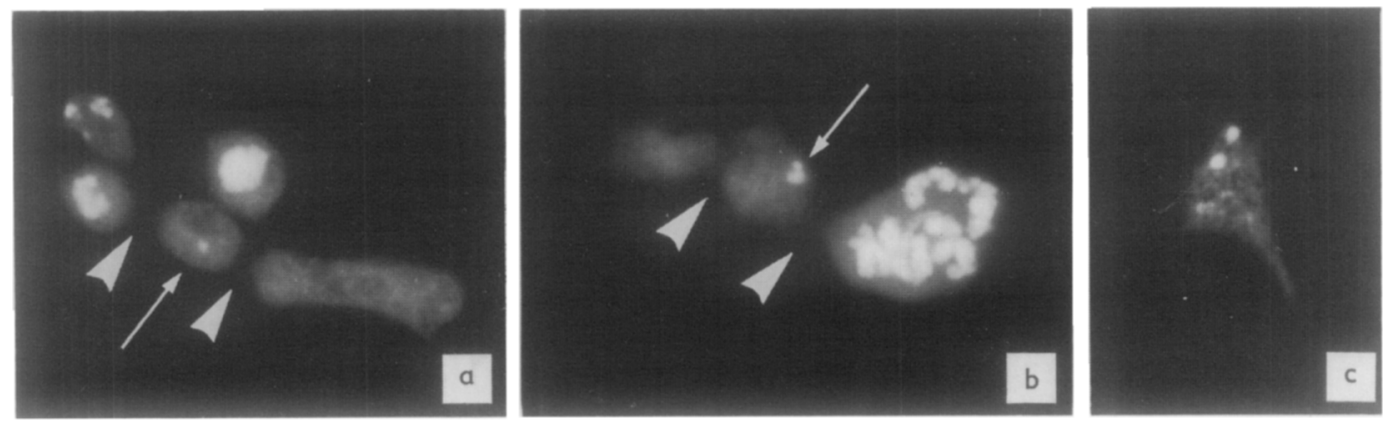

Fig. 2. $(a),(b)$ Two examples of mitotic cells having abnormally divided in a culture treated with colchicine for one day and, thereafter, been fixed and stained with acridine orange. The bright fluorescing chromosomes stand out clearly against the weak fluorescing cytoplasm of the cell fragments which are still connected with each other by small cytoplasmic bridges, as marked by heavy arrows. The numbers of chromo-

scored in a Neubauer chamber [3]. Those protoplasms which were obviously smaller in size than normal mitotic cells were assumed to be fragments in this test.

\section{Autoradiography}

For autoradiography $\left[{ }^{3} \mathrm{H}\right]$ leucine (Amersham-Buchler, $55 \mathrm{Ci} / \mathrm{mM}$ ) was used. The final activity was $50 \mu \mathrm{Ci} / \mathrm{ml}$ of medium. After $12 \mathrm{~h}$ of incubation fixation with methanol was performed as described above. In addition three rinses with an acetic acid/methanol mixture $(1: 3)$ were carried out, each rinse of at least 10 min duration, in order to remove unincorporated precursors. Appropriate pieces were cut off from the bottom of the plastic Petri dishes and covered with Kodak stripping film AR 10. After an exposure time of 7-20 days the autoradiographs were developed according to standard procedures and stained with Giemsa. Autoradiographs were analyzed microscopically by classifying cells and cell fragments in random fields into one of groups A-F (see results) and by scoring the percentage of labeled cells and fragments respectively. Those cells and fragments in which the grain density was undoubtedly $(\geqslant 10 \times)$ higher than background were considered as labeled.

\section{Time-lapse cinematography}

A video camera was adapted to the microscope (Zeiss Universal or Leitz Diavert) and combined with a monitor and a time-lapse videotape recorder (Sanyo VTR 1360). Cells and cell fragments were observed in phase contrast using a special chamber described elsewhere [4]. HEPES-buffered medium was used to keep $\mathrm{pH}$ constant at about 7.2. The microscope was placed into a thermoregulated box at $37^{\circ} \mathrm{C}$. somes contained in each fragment differ greatly. Occasionally very few (marked by light arrows), or even no chromosomes are detectable. $(b)$ indicates the possibility that cell fragments might be formed lacking in only very few chromosomes; (c) single fragment which had spread on the dish surface $14 \mathrm{~h}$ after a fragment suspension was pipetted into the dish. It contains two small clusters of chromatin. $\times 860$.

\section{RESULTS}

\section{Fragmentation of cells treated with colchicine}

When cultures were treated with colchicine for $24 \mathrm{~h}$, a large proportion of mitotic cells fragmented, giving rise sometimes to as many as a dozen or more fragment entities. The process of fragment formation in colchicine-containing medium was investigated using time-lapse cinematography. Fig. 1 shows two examples. The cells went into mitosis but became arrested in metaphase [5]. Over several hours no further change in the metaphase cells was visible, but later "protrusions" of different sizes were suddenly formed at different sites of the cell membrane (fig. $1 b$ ). These protrusions subsequently either regressed or led to the formation of fragments which often became completely separated while some remained connected with each other by small cytoplasmic bridges. The process of fragmentation itself was completed within a few minutes after the appearance of the protrusions. It was observed that totally separated fragments could cleave again by 
Table 1. Composition of samples obtained after incubation of fragment-suspensions for various times

\begin{tabular}{llllllllll}
\hline & $\begin{array}{l}\text { Cell } \\
\text { strain }\end{array}$ & \multicolumn{1}{c}{$t(\mathrm{~h})$} & $n$ & $\begin{array}{l}\mathrm{A} \\
(\%)\end{array}$ & $\begin{array}{l}\mathrm{B} \\
(\%)\end{array}$ & $\begin{array}{l}\mathrm{C} \\
(\%)\end{array}$ & $\begin{array}{l}\mathrm{D} \\
(\%)\end{array}$ & $\begin{array}{l}\mathrm{E} \\
(\%)\end{array}$ & $\begin{array}{l}\mathrm{F} \\
(\%)\end{array}$ \\
\hline Control & 1 & - & 210 & 96.5 & $1^{a}$ & 0 & $2^{b}$ & 0 & 0.5 \\
Expt 1 & 1 & 6 & 235 & 19 & 4 & 0 & 75 & 1 & 1 \\
& & 20 & 150 & 48 & 21 & 5 & 23 & 2 & 1 \\
& & 40 & 167 & 45 & 32 & 1 & 8 & 2 & 11 \\
Expt 2 & 1 & 120 & 106 & 65 & 23 & 0 & 1 & 0 & 2 \\
Expt 3 & 2 & 14 & 301 & 25 & 20 & 2 & 43 & 8 & 2 \\
\hline
\end{tabular}

$t$, Incubation time (hours) of sample before fixation.

$n$, Number of cells and cell fragments classified in groups A-F. For morphological criteria used for classification, see text. A, "normal" cells; B, multinucleate cells and cell fragments; C, cell fragments with one micronucleus; D, cells and cell fragments containing very condensed chromatin; F, apparently dead cells and cell fragments.

${ }^{a}$ Binucleate cells only.

${ }^{b}$ Mitotic cells.

Samples were stained with hematoxylin-eosin. In expt 2 only those cells and cell fragments were used for seeding which were found in the trypsin solution after a 1-min rinse. Control cells of strain 2 are not included in table 1, because they showed very similar results as compared with the data indicated for control cells of strain 1 .

furrow formation (fig. $1 f-h$ ). Remarkably, fragments were seen to exhibit distinctive and obviously active alterations of form (see p. 351, "Viability of cell fragments").

Staining with acridine orange revealed an irregular distribution of the chromosomes (fig. 2). The fragments contained one or several clusters of chromosomes, and in a substantial part of the fragments very little or even no chromatin was detected. The term cell fragment will be used when it is assumed that a protoplasm contains obviously less than its normal set of chromosomes or less than the normal amount of cytoplasm.

\section{Composition of samples}

Fragment-suspensions were placed into Petri dishes and samples were obtained as described under Material and Methods. Cells and cell fragments were stained with acridine orange or hematoxylin-eosin and classified into one of the groups A-F according to morphological criteria (see below). The percentages obtained for each group in samples scored after different times of incubation are given in table 1.

Group A: Normal cells. All cells containing one nucleus with a nuclear area larger than $75 \%$ of the smallest nuclei of the control cells (figs $4 a, 5 a$ ) were presumed to have a normal content of chromatin. By this rough criterion, of course, the loss of a small amount of chromatin cannot be excluded. Therefore, the percentage of group A given in table 1 represents an upper limit of normal cells. Normal cells in the samples descended either from viable interphase cells which detached from the surface of the culture flask while being shaken (see Material and Methods) or from mitotic cells which formed two normal daughter cells after the metaphase arrest was raised.

Group B: Multinucleate cells and cell fragments ( $B$-fragments). Protoplasms classified into group B (fig. 3) contained two or more karyomeres. About one quarter of these protoplasms were binucleate, about two-thirds had between 3 and 10 karyomeres. The maximum number of karyo- 

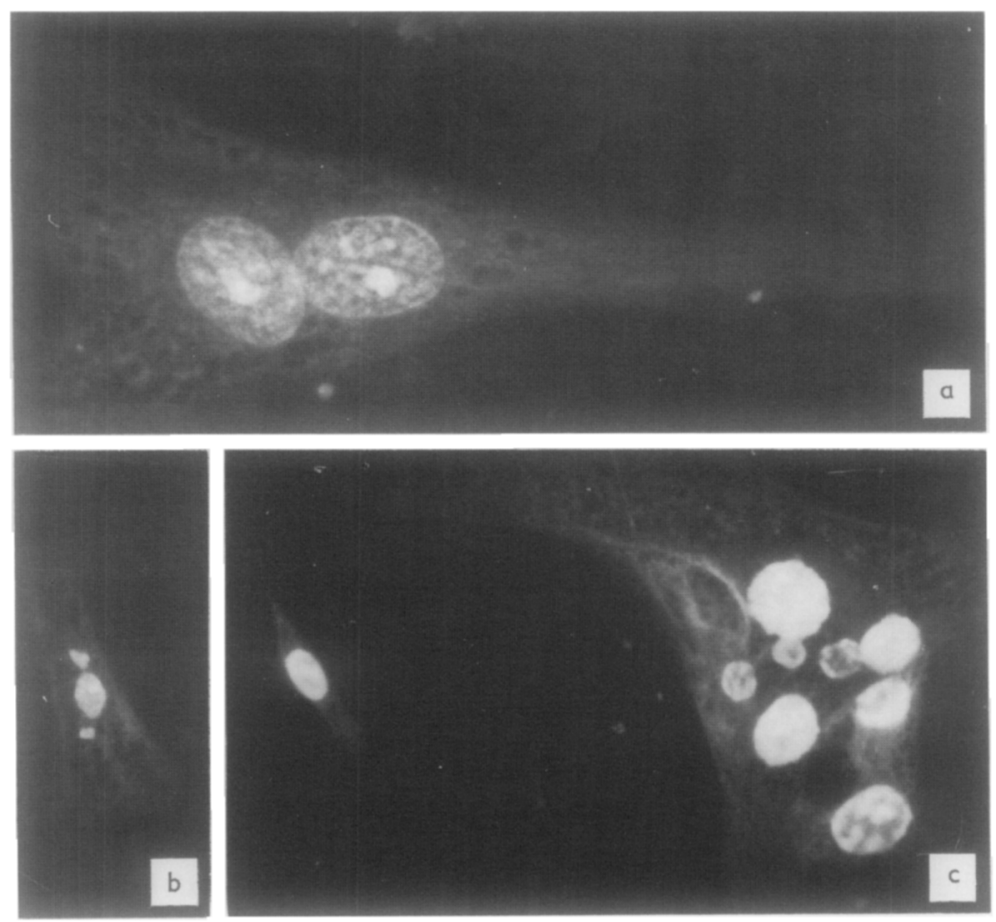

Fig. 3. (a) Binucleate cell from a control Petri dish not treated with colchicine; $(b)$ multinucleate cell fragment; (c) multinucleate cell (right) and cell fragment containing one micronucleus (left). Staining: acridine orange. $\times 860$.

meres was between 30 and 40 , but such cases were rare. While large multinucleate protoplasms presumably represent multinucleate cells which arose from abnormal anaphases of mitotic cells without cell division, the occurrence of very small multinucleate protoplasms (B-fragments) (fig. $3 b$ ) could be attributed to abnormal anaphases followed by cell fragmentation. Fig. $5 c$ shows the size distribution of the areas of 137 karyomeres contained in 29 multinucleate cells and cell fragments. Eighty percent of these karyomeres were smaller than the smallest nuclei in the control sample (compare fig. $5 a$ with $5 c$ ). DNA determinations based on Feulgen microspectrophotometry performed by Ege \& Ringertz [6] showed that the mean DNA content of karyomeres of multinucleate cells obtained by colchicine treatment is considerably smaller than the DNA content of nuclei of untreated cells. Karyomeres which are reduced in size because they contain less than the whole set of chromosomes have been termed micronuclei $[1,6]$. Morphologically these micronuclei appear similar to normal nuclei [1].

Group C: Cell fragments with one micronucleus (C-fragments). The amount of cytoplasm and the size of one karyomere contained in C-fragments was clearly less than in control fibroblasts (compare fig. $4 a$ with figs $4 b-d$ and $3 c$ ). The little karyomeres were assumed to be micronuclei by the following criteria: (a) The nuclear area was smaller than $75 \%$ of the area of the smallest nucleus observed in the controls; $(b)$ they showed zones of dispersed and condensed chromatin like karyomeres of control cultures or karyomeres of groups A and B; (c) the intensity of staining of these karyomeres was comparable to that of control karyomeres and karyomeres of groups $\mathrm{A}$ and $\mathrm{B}$, respectively. The argument that the colchi- 

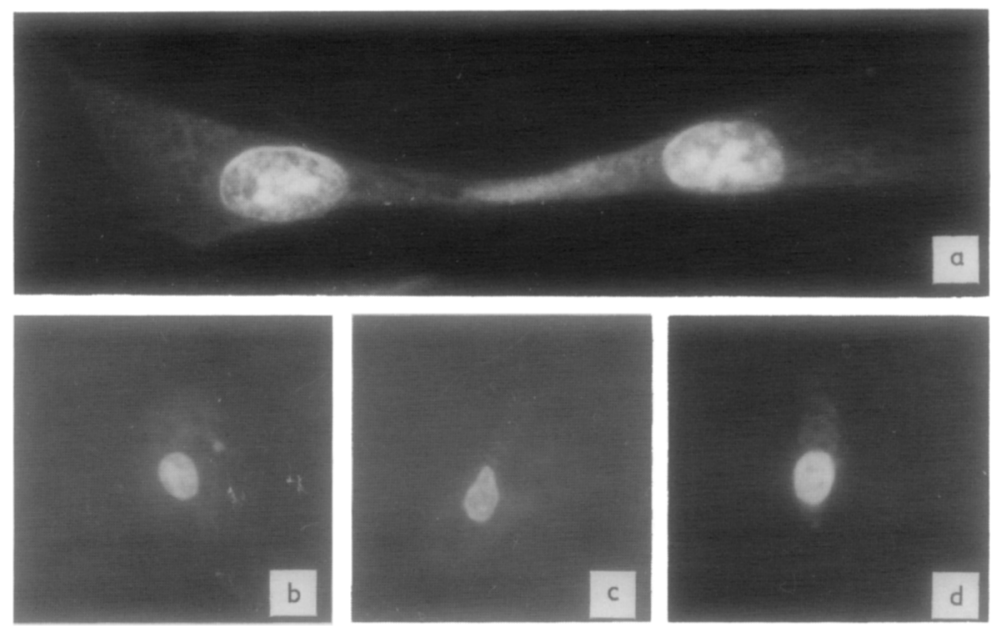

Fig. 4. (a) Two control cells with small nuclei from a Petri dish not treated with colchicine. Nuclear areas 104 and $98 \mu \mathrm{m}^{2} ;(b)-(d)$ three cell fragments each containing one micronucleus. Staining: acridine orange. $\times 860$.

cine treatment could generally reduce the size of nuclei was excluded: In 170 control fibroblasts (fig. $5 a$ ) the mean nuclear area was $202 \pm 97 \mu \mathrm{m}^{2}$ (S.D.). The mean nuclear area ascertained for 78 mononucleate cells of a culture treated with colchicine $(0.02-$ $0.04 \mu \mathrm{g} / \mathrm{ml}$ ) over a period of $24 \mathrm{~h}$ was $205 \pm 96 \mu \mathrm{m}^{2}$, while that of 63 mononucleate cells treated for $70 \mathrm{~h}$ was $224 \pm 76 \mu \mathrm{m}^{2}$. The proportion of $\mathrm{C}$-fragments found in the cultures after colchicine treatment was too small to decrease the mean nuclear area obtained from mononucleate protoplasms to any considerable extent.

Green fluorescing micronuclei of groups $B$ and $C$ occasionally revealed a red fluorescing spot when stained with acridine orange. This spot probably represented a nucleolus, since normal cells stained with acridine orange showed red fluorescing nucleoli within green fluorescing nuclei. The size distribution of the micronuclei obtained from $59 \mathrm{C}$-fragments was found to be similar to that of micronuclei in multinucleate protoplasms (fig. $5 b, c$ ). Occasionally Cfragments were seen connected by small cytoplasmic bridges to multinucleate protoplasms. These observations support our conclusion that $\mathrm{C}$-fragments were formed by abnormal cytokinesis and contained a reduced amount of chromatin.

Group D: Cell fragments which contain one or several clusters of very condensed chromatin. While B-fragments and C-fragments showed micronuclei as described above, in the large majority of cell fragments the chromatin remained in a very condensed state and formed one or several clusters (D-fragments) (fig. 2). At a high magnification it could be often observed that the clusters were composed of an aggregation of single metaphase chromosomes. As shown in fig. 2, the amount of chromatin could be very small and differed from fragment to fragment.

The large majority of cases classified into group D was clearly smaller in size than normal interphase and mitotic cells. The mean area occupied on the dish surface by 200 D-fragments obtained from samples was found to be $76 \pm 52 \mu \mathrm{m}^{2}$ (S.D.). In a control culture fixed with methanol, the mean area occupied on the dish surface by 28 mitotic cells was established to be $150 \pm 34 \mu \mathrm{m}^{2}$ (S.D.); the mean area occupied by normal interphase cells depended on cell density 


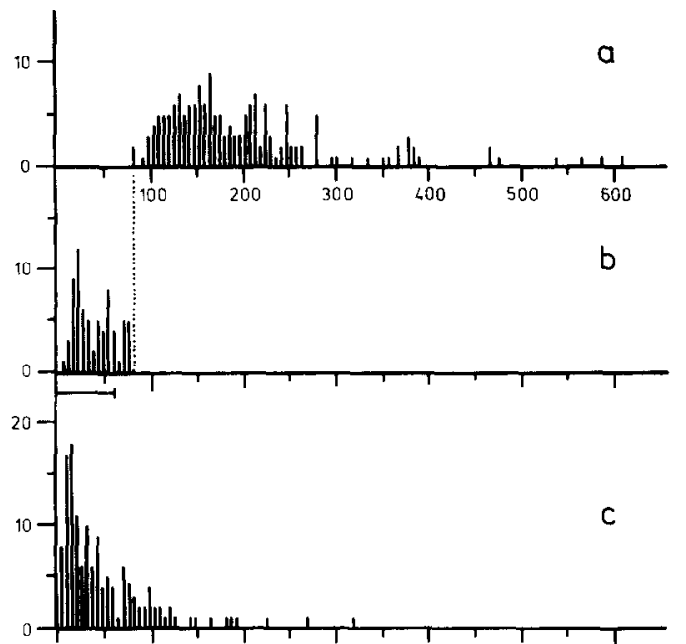

Fig. 5. Abscissa: nuclear area $\left(\mu \mathrm{m}^{2}\right)$; ordinate: no. of nuclei and micronuclei. Cells and cell fragments were stained with acridine orange.

Size distribution of nuclei and micronuclci. (a) $\mathrm{Nu}$ clear areas of 170 fibroblasts not treated with colchicine (control cells); (b) nuclear areas of 70 small mononucleate cells and cell fragments selected from a sample fixed $15 \mathrm{~h}$ after seeding. They contained each only one micronucleus or nucleus smaller than the smallest nucleus of the control cells. The horizontal bar indicates the size distribution of micronuclei of 59 C-fragments. The size distribution of nuclei with normal sizes is not shown (see text); (c) nuclear areas of 137 karyomeres contained in 29 multinucleate cells and cells fragments of the sample.

and was in every case much larger. The smallest interphase cells covered an area of at least $300 \mu \mathrm{m}^{2}$, the largest ones an area of more than $2000 \mu \mathrm{m}^{2}$. Taking into consideration that the mitotic cells were approximately ball-shaped, while many D-fragments sown into a Petri dish became more or less flat spread on the dish surface, it is evident that many of the latter contained much less cytoplasm than normal mitotic cells and interphase cells. A certain percentage of cases classified in group D may represent mitotic cells which performed abnormal anaphases but did not produce fragments or develop into multinucleate cells.

Group E: Cell fragments in which chromatin was not found. An example of such a fragment is shown in fig. $2 a$. It cannot be excluded that some fragments classified into this group contained a single chromosome which escaped detection.

Group F: Apparently dead cells and cell fragments (table $l, F$ ). The main criterion for this classification was that cells or cell fragments showed a state of lysis. It is not claimed that all the fragments classified into groups B, C, D and E were viable. The experiments described below, however, show that these fragment types were indeed viable for some time in a considerable number.

\section{Viability of cell fragments}

Roughly $70 \%$ of cell fragments in freshly prepared fragment-suspensions excluded trypan blue indicating an intact cell membrane. When suspensions were pipetted into Petri dishes, fragments were able to attach to and spread out on the surface in considerable number (figs $2 c, 3 b, 4 b-d$ ). But $120 \mathrm{~h}$ after seeding (table 1), fragments belonging to groups $\mathrm{C}, \mathrm{D}$ and $\mathrm{E}$ had disappeared from the samples. The samples still contained a considerable percentage of multinucleate cells. Very small multinucleate protoplasms which could be classified with certainty as B-fragments (fig. $3 b$ ) could, however, no longer be detected.

Table 1 shows no C-fragments after $6 \mathrm{~h}$, though these were present at later times. This might be a mere accident due to the small sample sizes from which the percentages were calculated. The majority of $\mathrm{C}$ fragments possibly survived during the first twenty hours after the fragment-suspension was placed into the Petri dishes, while a large number of D-fragments degenerated and detached from the surface. This might explain why the percentage of C-fragments shows a relative increase during the first day. It was not investigated whether frag- 
ments containing single chromosomes were able to form micronuclei or whether B- and C-fragments were directly produced by fragmentation of cells in which micronuclci had already developed. But obviously many D-fragments degenerated without further development. Fifteen hours after a fragment suspension was placed in a Petri dish, about $50 \%$ of the cell fragments were not attached to the surface of the Petri dish. The marked loss of D-fragments from the samples during the first 2 days of incubation was not accompanied with a comparable increase of B- and C-fragments (table 1). Since only those fragments still adhering to the dish surface after the fixation procedure including three rinses with Hanks' solution were counted, the majority of dead cell fragments was not included in the scorings (table 1, F). It was shown by Stubblefield [5] that metaphase arrest produced by colcemid lasted for an average of $12 \mathrm{~h}$, and was followed by both normal and abnormal anaphases. Metaphase arrests lasting for many hours were also found in our own time-lapse cinematographic observations. Despite removal of the medium containing colchicine it seems possible that mitotic cells contained in the fragment-suspensions could give rise even after several hours to normal interphase cells, multinucleate cells and cell fragments. The increase of percentages in groups A and B during incubation of the fragment suspension could be due to both new formation of normal interphase cells and multinucleate protoplasms during the first day and to the decrease of D-fragments.

The experiments shown in table 1 were not intended to investigate minor variations. It is only concluded that D-fragments established the predominant fragment type while the proportions of C- and E-fragments in the samples were small, and that these fragments degenerated within a few days.

Two kinds of experiments were performed in order to investigate the viability of attached fragments more precisely: timelapse cinematography in order to investigate motility and $\left[{ }^{3} \mathrm{H}\right]$ leucine incorporation in order to show protein synthesis.

\section{Motility of cell fragments}

When cell fragmentation was observed using time-lapse cinematography (one picture per second) it was found that the outline of newly formed fragments changed continuously. Using an accelerated motion play back 60 times faster than the timelapse recording speed the motility of fragments, including even the very small fragments shown in fig. $1 c, d$, appeared so rapid and varied that it was difficult to follow the changes in detail. Fragments became thicker at one side and thinner at another and vice versa. Fragments which were able to spread on the surface continuously extended and retracted numerous pseudopodia which were about one to several $\mu \mathrm{m}$ in length. Any moving point on the edge of such a fragment showed a repetitive protrusion and withdrawal resulting in irregular fluctuations of the whole edge or at least of several sites. The speed with which pseudopodia were extended or retracted was several $\mu \mathrm{m} / \mathrm{min}$. These fluctuations appeared very similar to those described by Abercrombie et al. [7]. Those fragments which clearly showed irregular fluctuations of their edges during a period of at least 5 to 10 min of observation were considered to exhibit active motility. Signs of active motility were not noticed in fragments which had detached from the surface.

Daughter cells of normal mitotic cells which were shaken off and allowed to reattach to the dish surface showed a motility 
as they spread on the surface resembling that of the fragments described above. But when flattened interphase cells had formed, movements of the whole edge slowed down or were restricted to a leading lamella [7]. Remarkably, fragments continued to perform irregular fluctuations of their edges even after they had spread on the surface. Since this kind of motility was performed, however, in all directions simultaneously, fragments did not migrate.

Accelerated motion play back of timelapse films showed such flattened fragments with rapid fluctuations besides interphase cells of normal size and appearance with little signs of motility. During prolonged microscopic observation (see below) motility of the fragments decreased or ceased. The observations possibly suggest that such fragments till they degenerated retained a motility typical for normal cells which spread out on a surface. Microscopic observation continued for many hours seemed to impair the viability of cells and fragments because of some unfavorable conditions of the observation procedure including bright illumination of the fragments. Therefore dishes containing fragment-suspensions were incubated up to $24 \mathrm{~h}$ before they were used for time-lapse cinematography. One hundred and six single fragments which had spread on the surface and were clearly smaller in size than the smallest normal cells were chosen and continuously filmed for at least $5 \mathrm{~min}$ up to $10 \mathrm{~h}$.

Active motility was found in 71 of the 106 observed fragments. The size of 45 fragments performing active motility was $\leqslant 100$ $\mu \mathrm{m}^{2}$, in some cases even considerably smaller. In order to establish the fragmenttype according to the morphological criteria described above some fragments exhibiting active motility were localized, fixed and stained after the observation was finished.
The majority of them was classified as Dfragments. Fifty-one out of 73 fragments which were filmed in dishes after $3-13 \mathrm{~h}$ of incubation exhibited active motility, while this was the case for 20 out of 33 fragments filmed in dishes after an incubation time of 18-32 h. Some fragments continued to show irregular fluctuations of their edge during $10 \mathrm{~h}$ of observation, although the intensity decreased after prolonged observation. In other fragments motility ceased after $2-4 \mathrm{~h}$ of continuous observation. The motility of the fragments filmed in dishes after $18 \mathrm{~h}$ of incubation appeared clearly slower than the motility of fragments filmed only after a few hours of incubation.

Possibly some fragments which performed motility in late observation periods arose from mitotic cells in which fragmentation occurred only after the fragment suspensions had been prepared. The proportion of mobile fragments is, of course, not representative for the whole number of fragments contained in the suspension, since those fragments which did not attach to the surface, or detached during incubation, or showed a state of lysis, were excluded from time-lapse observation. But in spite of these limitations the observations demonstrate that some fragments were able to maintain their motility for many hours.

\section{$\left[{ }^{3} \mathrm{H}\right]$ leucine incorporation}

Freshly prepared fragment-suspensions were pipetted into Petri dishes. After 5 and $20 \mathrm{~h}$ respectively $\left[{ }^{3} \mathrm{H}\right]$ leucine was added. The labeling period was $12 \mathrm{~h}$, i.e. fixation was performed after 17 and $32 \mathrm{~h}$ respectively. Almost all cells and cell fragments classified into groups A, B, and C and a considerable portion of fragments $D$ and $E$ got labeled during both labeling periods. The grain density observed over the fragments 
Table 2. $\left[{ }^{3} \mathrm{H}\right]$ leucine incorporation by $D$ fragments of different sizes

\begin{tabular}{llllll}
\hline & \multicolumn{3}{l}{ Labeling period } \\
\cline { 2 - 3 } $\begin{array}{lllll}\text { Fragment size } \\
\left(\mu \mathrm{m}^{2}\right)\end{array}$ & $\mathrm{A}$ & & & $\mathrm{B}$ \\
\cline { 2 - 3 } \cline { 5 - 6 } & $n$ & $l(\%)$ & & $n$ & $l(\%)$ \\
\hline $\mathrm{D}_{1} \leqslant 50$ & 226 & 55 & & 388 & 31 \\
$\mathrm{D}_{1}<\mathrm{D}_{2} \leqslant 100$ & 109 & 68 & & 104 & 58 \\
$\mathrm{D}_{3}>100$ & 293 & 96 & & 189 & 92 \\
\hline
\end{tabular}

$n$, number of fragments counted.

$l$, percentage of labeled fragments.

Both labeling periods A and B lasted for $12 \mathrm{~h}$. They were started 5 and $20 \mathrm{~h}$ respectively after the fragmentsuspension was placed into Petri dishes.

was often obviously lower than over normal cells contained in the same autoradiograph. But there were also small fragments which were labeled as densely as normal cells. Since D-fragments constitute the majority of fragments, they were examined a little closer. The result is shown in table 2 . The percentage of labeled fragments was found higher in larger D-fragments than in smaller ones. The labeling index of larger D-fragments did not decrease in the second labeling period, while a marked decrease was observed in small D-fragments. One could possibly expect a more pronounced decrease of labeled fragments, but those degenerated fragments which detached from the surface were no longer present and could not influence scoring.

\section{DISCUSSION}

Time-lapse cinematography revealed complete fragmentation of colchicine-treated diploid human fibroblasts into a number of cell fragments containing varying amounts of chromatin and cytoplasm. The effect seems to depend on the cell line used, since other authors using other cell lines only described multinucleation but not cell fragmentation in cultures treated with colcemid or colchicine $[1,5,6]$. Stubblefield [5] used time-lapse cinematography to analyse the mitotic activity of colcemidtreated Chinese hamster cells. He presented a sequence of photographs showing a cell cut by three cleavage furrows, but the furrows later regressed and a trinucleated cell was formed [5]. Cell fragmentation resulting in completely separated cell fragments as described above was not observed in the experiments of Stubblefield (personal communication (1975)).

Colchicine presumably acts by binding to protein subunits of the microtubules [8], while microfilaments which seem to form a contractile ring on which cytokinesis depends directly [9], appear unchanged in colchicine-treated cells [10]. Since microtubules are required for spindle function [8] this effect explains abnormal anaphases of colchicine-treated cells [1]. No explanation can be offered for the process of cell fragmentation induced by this drug. We suggest, however, that fragmentation is caused by interference of colchicine with regulating processes of cytokinesis, so that several contractile rings are formed. Several observations concerning the functions of microtubules support this suggestion. Microtubules seem to determine the topographical organisation of cell membrane components [11] and it was suggested that they are closely integrated together with microfilaments in regulating cell division [12]. During mitosis the orientation of the spindle apparatus may determine the site at which the contractile ring of microfilaments would be formed [9]. Time-lapse cinematography suggests that only mitotic cells were able to perform cell fragmentation. Formation of micronuclei and cell fragments was also observed occasionally in Chinese hamster cells which were microirradiated with a 
UV-laser microbeam during metaphase [13]. Cell fragmentation was never observed when either nuclei or cytoplasm of interphase cells were microirradiated [4].

Our observations show that cell fragments with a substantially reduced genetic complement and cytoplasm are viable in different respects, but cannot survive very long. They exclude trypan blue, show continuous motility and incorporate $\left.{ }^{3} \mathrm{H}\right]$ leucine. In the present experiments, however, it cannot be excluded that fragments which possibly had lost only a very small amount of chromatin and cytoplasm survived for more than $120 \mathrm{~h}$. The reason for a strongly limited lifespan could either be that parts of the genetic complement essential for basic cell metabolism were lost or that the chromatin did not become genetically active in the cell fragments. In addition, the effects of a reduced amount of cytoplasm have to be considered, because minicells, though containing a whole nucleus, fail to regenerate a cytoplasm and ultimately die [14].

Cell fragments containing fractional parts of a karyotype may be used for cell hybridization experiments like microcells obtained by the techniques of Ege \& Ringertz [6, 15]. While C-fragments may resemble microcells, though the latter contain obviously less cytoplasm, fragments which contain a reduced number of single chromosomes (Dfragments) or no chromatin at all (E-fragments) represent new fragment-types and might offer special possibilities in cell hybridization experiments.
Further investigations of the process of cell fragmentation induced by colchicine might contribute to a better understanding of the functions of microtubules in cell division.

We are indebted to Professors G. Kiefer, K. Sander, and U. Wolf, Freiburg i.Br., for helpful discussions. This work was supported by the Deutsche Forschungsgemeinschaft (SFB 46).

\section{REFERENCES}

1. Phillips, S G \& Phillips, D M, J cell biol 40 (1969) 248.

2. Hayflick, L, Exp cell res 37 (1965) 614

3. Phillips, H J, Tissue culture methods and applications (ed P F Kruse, jr \& M K Patterson, jr), p. 406. Academic Press, New York and London (1973).

4. Cremer, C, Cremer, T, Zorn, C \& Schoeller, L, Radiat res (1976). In press.

5. Stubblefield, E, Symp of the intern society for cell biology, vol. 3, p. 223. (1964)

6. Ege, T \& Ringertz, N R, Exp cell res 87 (1974) 378.

7. Abercrombie, M, Heaysman, J E M \& Pegrum, S M, Exp cell res 59 (1970) 393.

8. Borisy, G G \& Taylor, E W, J cell biol 34 (1967) 535.

9. Wessels, N K, Spooner, B S, Ash, J F, Bradley, M O, Luduena, M A, Taylor, E L, Wrenn, J T \& Yamada, K M, Science 171 (1971) 135.

10. Goldman, R D, J cell biol 51 (1971) 752 .

11. Becker, J S, Oliver, J M \& Berlin, R D, Nature 254 (1975) 152.

12. Van den Brenk, H A S \& Stone, M G, Nature 251 (1974) 327.

13. Zorn, C, Cremer, C \& Cremer, T, Proc electrooptics intern conf, p. 203. Kiver Communications, Surrey, UK (1974).

14. Ege, T, Hamberg, H, Krondahl, U, Ericsson, J \& Ringertz, N R, Exp cell res 87 (1974) 365.

15. Ege, T, Krondahl, U \& Ringertz, N R. Exp cell res 88 (1974) 428.

Received January 20, 1976

Accepted February 25, 1976 